but the present preliminary results suggest that the differences found in the slimes of these strains, as represented by the fractions analysed, are not sufficient to account for the host specificity of these plant pathogens.

Colonial Microbiological Researe

Port of Spain, Trinidad, West Indies.

1 Kelman, A., N. Carolina Agric. Exp. Stat. Tech. Bull., No. 99 (1953). 2 Husain, A., and Kelman, A., Phytopathology, 48, 155 (1958).

8 Rondle, C. J. M and Morgan, W. T. J., Biochem 61,586 (1955)

4 Hough, L., Jones, J. K. N., and Wadman, W. H., J. Chem. Soc., 1702 (1950)

s Stoffyn, P. J., and Jeanloz, R. W., Arch. Biochem. Biophys., 52, 373 (1954)

- Aminoff, D., Morgan, W. T. J., and Watkins, W. M., Biochem. J., 51, 379 (1952).

${ }^{7}$ Moffat, E. D., and Lytle, R. I., Anal. Chem., 31, 926 (1959).

\title{
EUGENICS
}

\section{Urinary Excretion of $\beta$-Amino-isobutyric Acid in Mongolism}

VARIous studies have suggested that the excretion of $\beta$-amino-isobutyric acid in human urine is under genetic control ${ }^{1-4}$. This amino-acid is derived from the metabolism of thymine via dihydrothymine and $\beta$-ureido-isobutyric acid ${ }^{5}$. Variation in excretion of $\beta$-amino-isobutyric acid may be controlled by a single gene pair, with high excretors being homozygous for a single recessive gene and low excretors being either heterozygous or homozygous for the dominant allele ${ }^{6}$. It also has been suggested that low and high excretors may differ in their metabolism of $\beta$-aminoisobutyric acid ${ }^{7}$. An increased incidence of high excretors has been found in certain ethnic groups, notably the Athabascan and Apache Indians of North America, the Black Caribs of British Honduras, and the Chinese and Japanese ${ }^{4,6,8}$. High excretors of $\beta$-amino-isobutyric acid are relatively uncommon in populations of Caucasian origin ${ }^{1,2,3}$.

Wright and Fink ${ }^{2}$ have reported an increased incidence of high excretors of $\beta$-amino-isobutyric acid in children who have mongolism (43 per cent) compared with normal children ( 7 per cent) and children who have unclassified mental deficiency (17 per cent). A proof of this finding was desired. A 47th chromosome has been observed in the cells of mongols ${ }^{10,11}$ and this extra chromosome may have biochemical effects.

In the present study, urine specimens were collected from 51 mongoloid children, 57 non-mongoloid mental defectives, and 61 normal children and were frozen until used. The creatinine concentration of each specimen was determined by a modification of the Jaffe reaction. Aliquots of urine containing $25 \mu \mathrm{gm}$. of creatinine were chromatographed twodimensionally on Whatman No. 1 paper in pyridine/ acetone/3 $N$ ammonia (45:30:25) followed by isopropyl alcohol/formic acid/water $(8: 1: 1)$. The chromatograms were sprayed with 0.2 per cent ninhydrin in 95 per cent ethanol, dried, heated at $80^{\circ} \mathrm{C}$. for $5 \mathrm{~min}$., and finally were sprayed with $0.25 \mathrm{~N}$ nickel sulphate solution. With this procedure, as little as $0.25 \mu \mathrm{gm}$. of $\beta$-amino-isobutyric acid can be detected readily. When $\beta$-amino-isobutyric acid was detected in a

Table ${ }^{5} 1$. URINARY FXCRETION OF $" \beta$-AMINo-isoBUTYRIO ACID BY MONGOLOID AND NORMAL CHILDREN AND BY NON-MONGOLOTD

B-Amino-isobutyric scid $\mu \mathrm{gm} . / \mathrm{mgm}$. creatinin Less than $70(0-66)$ More than $70(88-288)$

Total CHILDREN
DEFECTIVES

$$
\text { Number of Subjects }
$$

$\begin{array}{ccc}\text { Mongoloid } & \text { Normal } & \begin{array}{c}\text { Non-mongoloid } \\ \text { defectives }\end{array} \\ 49 & 57 & 54 \\ 2 & 4 & \frac{3}{57} \\ \overline{51} & \overline{61} & \overline{57}\end{array}$

urine specimen, the amount was determined on paper chromatograms by visual comparison of spots obtained from appropriate aliquots of urine with those obtained from graded amounts of the authentic compound. Chromatography was carried out in a special 'smog'-free room, in order to avoid the destructive effects of oxidants present in the Los Angeles atmosphere.

The data on urinary excretion of $\beta$-amino-isobutyric acid are presented in Table 1. Only 4 per cent of the mongols, 5 per cent of the non-mongoloid mental defectives, and 7 per cent of the normals are high excretors; that is, individuals excreting more than $70 \mu \mathrm{gm}$. of $\beta$-amino-isobutyric acid per mgm. of creatinine. The range of $70-200 \mu \mathrm{gm}$. per $\mathrm{mgm}$. of creatinine was suggested by Harris ${ }^{1}$ for high excretors following an examination of 345 subjects, and also was used by Calchi-Novati et al. ${ }^{2}$ with 792 subjects. A distinct high excretor group was not observed by Gartler in one study ${ }^{3}$ : more recently, however, Allison, Blumberg, and Gartler ${ }^{6}$ have presented results which appear to confirm the range selected by Harris $^{1}$ for high excretors. The low percentage of high excretors found among mongols in the present investigation is comparable to that reported by others $^{1,2,3}$ for normal individuals of Caucasian origin.

The excretion of $\beta$-amino-isobutyric acid was expressed by Wright and Fink ${ }^{9}$ in terms of urine volume. The significance and reproducibility of this parameter are questionable because the dilution of different urine specimens can vary greatly; it is more reliable to use a timed collection period or volumes containing equivalent amounts of creatinine. The present results, nonetheless, were recalculated on the same basis for the purpose of comparison : 6 per cent of the mongols, 5 per cent of the nonmongoloid defectives, and 10 per cent of the normal subjects excreted 0.5 to 9.0 millimoles of $\beta$-aminoisobutyric acid per litre of urine, which was the range designated by Wright and Fink ${ }^{9}$ for high excretors. The difference in the percentage of high excretors in the three groups of subjects is not significant, regardless of the manner of computation, and it is concluded that the incidence of high excretors is not increased in mongolism.

We are grateful to Rosemary Summers for collecting urine specimens, and to Jane Traub for technical assistance. We are indebted to Dr. Marvin D. Armstrong for suggesting the chromatographic solvents, and to Dr. Linus Pauling for helpful criticism. This study was supported by the Ford Foundation.

Thomas L. Perry

KenNeTh N. F. SHAw

DOROThY WALKER

California Institute of Technology,

Pasadena, California and

Pacific State Hospital,

Pomona, California.

\footnotetext{
1 Harris, H., Ann. Eugenics, 18, 43 (1953).

Calchi-Novati, C., Ceppellini, R., Biancho, I., Silvestroni, E., and Harris, H., Ann. Eugenics, 18, 335 (1954)

Garter,

- Gartler, S. M., Firschein, I. L., and Kraus, B. S., Amer. J. Human

Genetics, 9, 200 (1957).
Fink, K., J. Biol. Chem., 218, 9 (1956).

- Allison, A. C., Blumberg, B. S., and Gartler, S. M., Nature, 183, 118 (1959)

Gartler, S. M., Arch. Biochem. and Biophys., 80, 400 (1959).

s De Grouchy, J., and Sutton, H. E., Amer. J. Human Genetics, 9, 76

Wright, S. W., and Fink, K., Amer. J. Mental Deficiency, 61, 530 (1957).

${ }^{10}$ Lejeune, J., Gauthier, M., and Turpin, R., C. R. Acad. Sci., Paris, 248, $602(1959)$ Jacols, P., Baikie, A. G., Court Brown, W. M., and Strong, J. A.,
Iancet, i, 710 (1959).
} 